\title{
INTERNATIONAL SERVICE LEARNING AMONG ISLAMIC HIGHER EDUCATION INSTITUTIONS: CHALLENGES AND STRATEGIES
}

\section{Sajidin}

Univeritas Islam Negeri (UIN) Sunan Gunung Djati Bandung

Jl. A.H. Nasution No. 105, Bandung, Jawa Barat, Indonesia, 40614

Email: sajidin@uinsgd.ac.id

\section{Andang Saehu}

Univeritas Islam Negeri (UIN) Sunan Gunung Djati Bandung

Jl. A.H. Nasution No. 105, Bandung, Jawa Barat, Indonesia, 40614

Email: andangsaehu@uinsgd.ac.id

\author{
Asyraf Isyraqi \\ Islamic Education Programme, Academy of Islamic Studies, University of Malaya \\ Jalan Universiti, Wilayah Persekutuan Kuala Lumpur, Malaysia, 50603 \\ Email: isyraqi@um.edu.my
}

Received: 03, 2020. Accepted: 06, 2020. Published: 06, 2020

\begin{abstract}
The study aims at exploring the implementation of International Service Learning (ISL) among Islamic Higher Education Institutions in Indonesia, its challenges, and strategies to cope with them. To explore the phenomena, six Islamic Higher Education Institutions (IHEI) implementing the ISL in Indonesia were purposively selected as sample of the study. A face-to-face interview with the respondents and document analysis towards relevant resources were employed as the main data collection techniques. After analysing the data and, later, triangulated them, the following findings emerge. First, the implementation of ISL was structurally carried out on the basis of preparation, implementation, and evaluation. Second, employing a framework of ISL implementation, coined by Baker-Boosamra, most recommeded steps were followed. Third, ISL among IHEIs encounter some challenges to cope with. Some could be successfully resolved; some others remain unresolved. The study recommends that ISL among IHEIs be properly managed by formulating specific objectives. The formulated objectives serve as the standard of ISL successful implantation.
\end{abstract}

Keywords: Islamic Higher Education Institutions, International Immersion, International Service Learning

\begin{abstract}
ABSTRAK
Penelitian ini bertujuan untuk. mengungkap pelaksanaan Kuliah Kerja Nyata Internasional (KKNI) di Perguruan Tinggi Agama Islam (PTAI) di Indonesia. Secara kbusus, penelitian akan mengungkap tantangannya, dan beberapa strategi untuk mengatasinya. Untuk mencapai tujuan tersebut, enam PTAI yang menyelenggatakan KKNI di Indonesia dipilih menjadi contoh dalam penelitian ini. Data diperoleh melalui wawancara langsung dengan para responden. dan analisis dokumen tentang pelaksanaan KKNI dari berbagi sumber. Setelah menganalisis data dan, kemudian melakukan triangulasi, temuan berikut muncul. Pertama, implementasi KKNI dilakukan secara sistematis berdasarkan persiapan, implementasi, dan evaluasi. Kedua, menggunakan kerangka kerja implementasi KKNI yang dirumuskan oleh Baker-Boosamra, umumnya ditemukan babwa sebagian besar langkah-langkahnya diikuti. Ketiga, KKNI di lingkungan PTAI menghadapi beberapa tantangan untuk segera diatasi. Beberapa bisa diselesaikan dengan sukses; beberapa lainnya tetap tidak terselesaikan. Penelitian ini merekomendasikan babwa agar pelaksanaan KKNI di lingkungan PTAI bisa dikelola lebih baik, maka pengelola program kegiatan barus sejak dari awal merumuskan tujuan yang ingin dicapai dari kegitian ini. Tujuan yang rinci dan spesifik menjadi patokan apakah pelaksanaan KKNI berhasil atau tidak.
\end{abstract}

Kata Kunci: Pendidikan Tinggi Islam Indonesia, Magang Internasional, Pembelajaran Layanan Internasional, 


\section{INTRODUCTION}

Service learning, interchangeably with the community service programs, has been an integral part of the school curriculum. In Higher Education, the program is integrated into a university program and is considered a non-credit hour course. It explicitly states that Higher Education (e.g. universities, colleges, and diplomas) has to carry out a community service project as a prominent tool in teaching and research project. The so-called Tri Dharma, meaning three pillars of Higher Education, is a must for Higher Education, as stated in the state regulation no 12, 2012, on Higher Education, article 2. The policy is effective for all universities or colleges (including Islamic Higher Education under the supervision of the Ministry of Religious affairs) across the country.

Despite the non-credit hour, service learning is of utmost significance and is quite central for Higher Education. It is a way to bridge the gap between university and community (Niehaus \& Crain, 2013), to gain increasing amounts of attention (Gaines-Hanks \& Grayman, 2009), 'to strengthen the interaction between academia and the world outside" (Chiu, 2015), to measure the extent to which the institutions meet the community need, to make a link between service providers and service recipients, and to match what the market is expecting with the curriculum being developed. In particular, service learning benefits several parties: students, service recipients, sponsoring organizations, and the larger community (Yin et al., 2004).

Research on service learning reveals that students gain more benefits. It improves students' life skills (Ansor, 2017; Cheryl Keen \& Kelly Hall, 2008; Chiu, 2015; Furco, 1996; Gaines-Hanks \& Grayman, 2009; Hartman \& Rola, 2000). By life skills, they can cope with life challenges and build a better life, which may cover personal skills, social skills, academic skills, and vocational skills. Research on service learning also indicates the steps to follow in the process of conducting service learning. The research by Baker-Boosamra, Guevera \& Balfour (2006) and Reisch (2011) showed that assessing the need would be the initial step to conduct service learning. Upon completing the need assessments, the stakeholders formulate the course objectives and set up the standard of achievement.

Nowadays, service learning has developed into more global and worldwide. In conjunction with the internationalization of higher education, several universities and colleges in the country set up service learning conducted in an international context. The so- called International Service Learning (ISL) - which takes one to six months in target countries - is believed to improve intercultural competence (Kohlbry \& Daugherty, 2015; Larsen \& Searle, 2017; Watzak, Engelhardt, Bentley \& Self, 2015), to promote global awareness (Larsen \& Searle, 2017; Schreier \& Prügl, 2011), and to foster civic responsibility/engagement on the part of the students. (Brown, 2015; Hartman \& Rola, 2000; Matson \& Barnas, 2014; Yin, Zhang, \& Wang, 2004) The students taking part in the program show those character traits even if they have completed it (Schreier \& Prügl, 2011). In this initial step, another research shows that orientation and training are important indicators of successful service learning implementation (see Niehaus \& Crain, 2013).

The previous research also showed that the next stage to be conducted is to immerse in the host community. Among relevant activities recommended by some experts are as follows: supervision, monitoring, tourism activities (Reisch, 2011), direct work in the communities, reflection, debriefing, home visit, collaboration with a local organization (Gura, 2010), journaling, and a final conference day (Baker-Boosamra et al., 2006a; Niehaus \& Crain, 2013). Debriefing can be conducted before, during, and after the immersion to deal with the feelings that may be connected with the experience (Amerson, 2014); meanwhile, collaborating with local organizations to form partnerships facilitates an ongoing relationship in the destination country). In particular, the reflection can involve the local people. Moreover, journaling is 
employed to promote reflection and self-evaluation (Gura, 2010). A final conference day is suggested as a way to keep the local community members abreast of what students have been involved with while in the host country, and to provide a venue for student or faculty-led evaluation of the various host agencies, and a forum to exchange social work techniques and recommendations (Baker-Boosamra et al., 2006a).

IAIN Tulungagung initiated ISL in Islamic Higher Education in Indonesia in 2012. It was then followed by UIN Maulana Malik Ibrahim, UIN Sunan Ampel, Surabaya, and STAIN Purwokerto. They send their students to neighbouring countries, such as Thailand, Malaysia, and Singapore. Thailand, particularly Southern Thailand, such as Naratiwat, Yala, and Pattani, tend to be their main destination for ISL due to several motivations. First, they relatively have the same culture, Malay cultures. They speak and behave like Indonesian in general. Second, they have the same religious adherence so that the students can easily get engaged with the local community. Third, there are a lot of alumnae from those provinces who studied in Indonesia; they can play as facilitators during communication with the government officials, and the local community in the host country. Following this, Kohlbry and Daugherty (2015) state that small group work positively affects students' involvement in their academic studies generally and their capacity to facilitate service learning in new situations.

Until recently, there is no specific information on how ISL among the Indonesian Islamic Higher Education Institutions was implemented, what challenges they encountered, and what strategies they made to cope with the challenges. The challenges in implementing ISL has been explored in Tanzania's Service learning Program (Nickols et al., 2013). The study focuses on the exploration of Internal/psychological challenges among the participants of ISL. Meanwhile, the present study focuses on the exploration of external challenges in implanting ISL in Indonesian Islamic Higher Education Institutions.

\section{METHOD}

The present study employed a descriptive-evaluative research design since the result of the study assessed participants' involvement (administers and participants) in the implementation of International Service Learning by conducting interviews and documentation. According to Arifin (2010), evaluation research is aimed to provide information for the decision makers (policy makers-administrators) related to power or strength of a program, seen from its effectiveness, cost, device, etc.

The current study involved 15 respondents from six Islamic higher education institutions in Indonesia consisting of Universitas Muhammadiyah Sumatera Utara (UMSU), Universitas Muhammadiyah Yogyakarta (UMY), Universitas Muhammadiyah Purwakarta (UMP), and Universitas Islam Negeri Sunan Ampel (UINSA), UIN Maulana Malik Ibrahim (UIN Malang), and IAIN Tulungagung. They played as administers and participants of the program. Briefly, the respondents are presented below.

Table 1. The Respondents of the International Service Learning

\begin{tabular}{llcc}
\hline No & \multicolumn{1}{c}{ IHEIs } & $\begin{array}{c}\text { Length of } \\
\text { Experience }\end{array}$ & \# of Respondents \\
\hline 1 & UMSU & 2 years & 3 \\
2 & UMP & 1 year & 2 \\
3 & UMY & 5 years & 2 \\
4 & UINSA & 4 years & 2 \\
5 & UIN Malang & 6 years & 4 \\
6 & IAIN Tulungagung & 5 years & 2 \\
\hline
\end{tabular}

The universities were selected to represent both private and public Islamic Higher Education Institutions in Indonesia. The private Islamic Higher Education Institutions under 
the supervision of Muhammadiyah Islamic Organization were selected since they have been initiators of International service learning in the country. Fifteen undergraduate students enrolled for joining the ISL program served as participants. They were the third-year undergraduate students taking Bachelor Program on English education department, Financial Management of Syariah department, and Islamic Religion department. They had attained courses in pedagogical content knowledge beforehand, such as EFL Methodology, Materials Development, Accounting, Banking, and Management.

The researchers utilized interviews, questionnaires, and documentation analysis to help us in obtaining the data. The first two instruments are to explore ISL's implementation among Islamic Higher Education Institutions in Indonesia, its challenges, and strategies to cope with them. The latter instrument assesses the paperwork (MoU drafts, Photos of ISL activities, and ISL reports) of the implementation of ISL among Islamic Higher Education Institutions in Indonesia. The decision on utilizing those instruments since they can provide a very economical and systematic way to ensure all relevant items considered for evaluation (Gall, Borg \& Gall, 2003).

The interviews were about the implementation of ISL starting from pre-trip, in-country, to post-trip activities, the challenges of its implementation, and the strategies to cope with them. Through documentation, some MoU drafts were collected between the universities and the institutions in the host country, some photos in pre, whilst, and post-trip activities, and the participants' reports of its implementation.

All the collected data were analysed using the steps proposed by Gall et al. (2003) such as identifying the data, categorizing the data, finding the data relationship, and developing the theory based on the categorized data. In working with the analysis, other processes happened. For example, data were reduced, tabulated, and finally concluded. The conclusion was drawn on the basis analysed and verified data.

\section{RESULTS AND DISSCUSSION}

Regarding the research questions, we find three major points: the implementation, challenges, and strategies.

\section{The Implementation of ISL: Background, the Roles of Stakeholders, and Procedures}

The implementation of ISL within Islamic Higher Education comes with different ideas and background. However, there seems to be a consensus among them that they need to internationalize their campus. It is in line with their vision in addressing the issue of global competitiveness. For example, the UMY has the following vision: "promoting a collaborative network among both national and international institution for the betterment of education, research, management and services". It is also explicitly stated from the interview with the respondent that the aim of ISL is for the internationalization of the university, "the focus is on the internalization of the institution. Parallel to this, UMSU has the following vision: "to realize a collaborative network among national institutions and international ones." The mission statement of UIN Malik Ibrahim Malang is formulated as follows: "Toward a World Class University and Become the Best Choice for Students from 16 Countries)."

The interview with a stakeholder UINSA strengthens the conclusion: "the first target of the ISL program is to internationalize the institution. The institution's vision and mission are international policy; therefore, the institution should go international in providing any service." The program is also developed to meet the National Standard of Education qualification, in which the universities with international collaboration are considered higher in terms of their points. Let us consider the following statement: "Since the Department of International Relationship stipulates its students visit other countries to get Grade ' $A$ ' in accreditation." 
Who takes part in the program, and what roles do they play? Several parties participate in the program within various stages: during preparation, implementation, and evaluation. Obviously, the International Offices (IO) plays a major role in all stages of the program. Prior to their trip, the International Offices (IO) build to international institutions in the host countries, such as The Consulate General, local organizations, and the target communities.

Table 2. The Unit Taking Part in the ISL

\begin{tabular}{lll}
\hline \multicolumn{1}{c}{ Unit Names } & \multicolumn{1}{c}{ Roles } & \multicolumn{1}{c}{ Remarks } \\
\hline Microteaching & Developing Teaching skills & $\begin{array}{l}\text { A case in UIN Surabaya, and } \\
\text { UMSU }\end{array}$ \\
$\begin{array}{l}\text { Quranic Memorization } \\
\text { Travel Agent }\end{array}$ & $\begin{array}{l}\text { Testing Quranic recital skills } \\
\text { Ticketting }\end{array}$ & $\begin{array}{l}\text { A case in UIN Malang } \\
\text { A case in IAIN Tulungagung }\end{array}$ \\
Host Country Alumni & $\begin{array}{l}\text { Introducing host cultures and } \\
\text { languages }\end{array}$ & $\begin{array}{l}\text { One day workshop } \\
\text { Within one year preparation (a } \\
\text { International Program }\end{array}$ \\
Language preparation & $\begin{array}{l}\text { case in UIN Malang) } \\
\text { Faculty of Psychology }\end{array}$ & $\begin{array}{l}\text { Administrating case in UMSU } \\
\text { motivation, interest, and skills }\end{array}$ \\
\hline
\end{tabular}

How is the program implemented ? Galvanised by Baker-Boosamra et al (2006a), the implementation of ISL within 6 Universities is presented below.

Pre-Trip Activities

As the name suggests, the activities deal with all preparation and orientation prior to the service learning in the host countries. The following are presented the activities evident in the implementation of ISL in Islamic Higher Education Institutions.

Preparing Knowledge (the study of the host culture, history and economy; pre-departure relationship building; basic target language instruction; and students' critical examination of power and privilege)

The first thing first in the pre-trip activities is preparing knowledge. Based on the interview with the stakeholders of UINSA, UMP, UIN Malik Ibrahim, UMSU, IAIN Tulungagung, and UMY, they showed the same notion that all participants must have knowledge of host culture, history and economy, host language, pre-departure relationship building, and students' critical examination of power and privilege. These knowledge preparations were then confirmed to the participants through the questionnaires. The main item questioned in the questionnaire is what did the committee do prior to departing to the host country? All participants showed their same wavelength in the notion that they had joined the training session called as academic and geographical orientation for three months.

The training may vary from a two-day short course to a one-year language program," the coaching and orientation take place in 2 days to one year on how to live abroad." The languages they learn are mostly English since it is considered a language for international communication. In addition to English, they also learn the host language, the language where their learning service is provided.

Having Contact with Host Partner Agencies Prior to Students' Placement

Another thing the universities did in the pre-trip activities is having contact with host partner's agencies. The evidence to this data was gained through the document analysis (memorandum of understanding- $-\mathrm{MoU}$ ) they shared. The confirmation of the document analysis was carried out via interviewing the stakeholders. The interview data indicated that they did correspondence with the institutions in the host country. The final result of correspondence is the $\mathrm{MoU}$ focusing on transportation, accommodation, and fees during the intensive service learning. 
The activity was carried out by UMSU, IAIN Tulungagung, and UINSA. The most popular host partner agency is a board of International graduates. They consist of alumni from Indonesian universities and international universities, particularly universities in the Middle East (e.g. Thailand case). The board helps the universities connect the host government agencies (such as General Consulate, security agencies, and the school administrators). They are also responsible for accommodation and permit letters required by the participants. For the universities under the supervision of Muhammadiyah (UMSU, UMY, and UMP), contacting host partner agencies before participants' placement was conducted among the host universities. They played as the facilitator of the program.

Familiarizing Participants with Their Respective Host Agencies Prior to Arrival in the Host Country

Having had a deal with the institutions in the host country, the universities' next thing was to familiarize participants with the respective host agencies. The role of host agencies is limited to organize the activities in host countries. One of the respondent's states, "Later, the entry permits and other invitations are part of their job, we do not need to handle them." They have no specific involvement in the country of the participants. Therefore, this stage is not carried out by all universities since there is no specific budget on the activity. The only UINSA attempted to familiarize them by arranging the program well. Meanwhile, the other universities became familiar with each other naturally without any arrangement. One of the stakeholders of UINSA said, "The participants familiarized the programs to the host agencies through e-mail so that prior to the arrival in the host country, the agencies helped us arranged and coordinated the program execution."

Promoting a Deeper Sense of Reciprocal International Understanding on Culture and

Belief, Increasing the Benefit of the Students' Presence to Partners

This is the follow-up session of the familiarizing the participants through their programs to the respective host agencies. As the only UINSA familiarized the programs, the promotion session was presented by UINSA. Based on the interview with the stakeholders, the focus of the promotion is on the reciprocal understanding of culture and belief. Meanwhile, UMP, UIN Malik Ibrahim, UMSU, IAIN Tulung Agung, and UMY seemed to promote it in the academic and geographical orientation session. They said, "we have provided a deeper sense of cross-cultural understanding in the three-months orientation session."

\section{In-Country Activities}

Employing a framework from Baker-Bosamra et al. (2006), the activities in this stage are formulated in the following stages:

Convening a Community Assembly

Based on the interview with the stakeholders, the in-country activity the participants did in the host country was to convene the community assembly. They said,

"the participants gave the detail of the program when arriving at the host country.

One of which was to say hello with the host community. The participants invited the community assembly to attend the session, and I was assigned to give the speech."

The result of the above interview is in line with the responses provided by the participants through the questionnaire. Their responses showed that they invite the community assembly to attend the opening or promoting program session.

Conducting Immersion and Dialogue with the Community

Having convened the community assembly, the participants immersed in the community to find the potential issues and opportunities in the host country. The questionnaire data showed that all participants conducted immersion and dialogue with the community as this activity is of utmost importance. 
Involving in Service Placements

The immersion conducted with the community provided some potential issues to be carried out during the ISL. The participants placed some services in the schools, the bank, the mosque, and the local government based on the questionnaire data. They got their own experiences pursuant to the places they were servicing during six months of service learning.

Hosting a Final Conference Day for Students and Host Agency Representatives

Prior to leaving the host country, the participants hold an evaluation and closing ceremony. The evaluation was conducted by their academic supervisors and host country supervisors. When interviewed, they said their supervisors evaluated their in-country activities from the preparation, the implementation, and the outcome. At the end of the evaluation, the closing ceremony was held with the local community, local government, academic supervisors, and host country supervisors.

\section{Post-Trip Follow Up and Continued Relationship Building}

The last activity is to report the implementation of ISL to the academic supervisors in various ways. The interview data showed that UMSU and UMP assigned the participants to write an online journal. The committee of ISL prepared a website for the sake of submitting the journal. UMY, UIN Malik Ibrahim Malang, UINSA, and IAIN assigned the participant to jot down a project report. Special for IAIN Tulungahung, the interview data indicated that the participants required to present the report in front of the junior students. This is to trigger and motivate the juniors to be curious and interested in holding the ISL.

\section{The Challenges of Implementation of ISL}

Employing the data of interviews as the source for analysis, the following challenges are identified: financial issues, political issues, language barriers, local community demands, relevant skills, cultural diversities, and geographical issues.

Financial Issues

Participants responded to the item about the challenges they encountered in the implementation of ISL. The great attention to the challenges was indicated to the financial issues. All participants from the six universities involved in this study had financial problems. This issue was confirmed through the interview with the stakeholders, saying that "it is true that the finance is of strong attention to the students."

Political Issues

The item of questionnaire relating to the security (hereafter called political issues) during staying in the host country paid special attention from the participants. As the guests for the host country, they required to prepare many things to make them safe and comfortable in the host country. As known that, for example, South Thailand is a country politically in security crises - a gun attack between the local army and the rebels. This phenomenon can affect the readiness and psychology of the participants to do ISL.

Language Barriers

Being able to speak in English is one of the requirements to join the ISL. Based on the questionnaire, the participants did not have any barriers to English. However, English became the language barrier for the host community as they could not speak English. On the contrary, the participants also had the language barrier as they could not speak the native language of the host country, such as Japanese, Tagalog, or Malay.

Host Country Demand

The universities, as a service provider, take some benefits from the program. For example, they can give overseas experiences to their students, and the participants get some free meals and accommodation for the host countries. To compensate, the host countries demand that the scholarship be provided for their students. One of the respondents uttered," one of community demands in partnership is that the service provider give scholarship for the 
local people." It is also proven in the following statements: "The participants have been financially supported there; the accommodations are prepared. They are given living costs. To compensate, the local community asked for scholarship for the people."

Necessitated Relevant Skills

ISL is mostly conducted in the schools in which the participants are challenged to teach. They have to provide services by teaching students. However, most participants have no prior knowledge of teaching. They study in non-teaching departments, like in UMSU. Thus, the participants hard to adapt to their current activities. However, based on the interview with the stakeholders of IAIN Tulungagung, the students played a role as expected, some of whom were teaching in the schools, servicing in the bank, assisting the local government, and helping the Islamic clergies in the mosque.

Cultural Diversities

The participants could not be easily engaged with the local community due to cultural differences. To achieve the target, that is - providing a good service, the participants need to be interculturally competent. Based on the questionnaire, most students in the target schools in which ISL is implemented are reluctant for to learn. One of the main factors is that the people, particularly in South Thailand, can easily get money even though they do not go to school. This may not be found in most Indonesian regions in which the students are most highly motivated.

Geographical Issues

ISL frequently takes a long journey from the country of origin to the host countries. It takes hundreds or thousands of mikes to reach by land or air transportation. In addition to this, the geographical situation may challenge the participants. This happens to the participants in South Thailand and the Philippine in which the participants are hard to reach the target community due to lack of transportation since they live in a remote area.

\section{The Strategies to Cope with the Challenges}

Responding to the challenges, the university conducted suggested strategies to encounter the issues emerging during the implementation of ISL as follows.

Financial Issues

The universities developed several strategies to cope with financial issues. Firstly, the participants take land transportation to cross the host countries rather than air transportation. This applies to ILS in South Thailand, in which to cross the country, the participants can go by bus or train. Next, the universities effort to make an agreement in the form of $\mathrm{MoU}$, in which all participants are given free meals and accommodation during their immersion. In this case, the host countries contribute to the reduction of the participants' living expenses. In addition to this, the students participate in the program get paid from the services they provide. The universities then draw the money from the participants several times following their capacity (instalment payment). Finally, the length of stay in the host countries is reduced to match the participants' budget.

Political Issues

The universities were firstly invited all relevant parties to the opening ceremony so that they know their existence and activities in the host countries. One of the respondents puts his opinion forwards, "after the opening ceremony, the officials from local government, as well as, from Indonesia General Consulate came to attend to see the participants of ISL. Their names have been recorded and spread to the Thai Army for further identification and security purposes." Then, the participants were given an ID card made by local governments.

Language Barriers

The challenge of the language barrier experienced by the participants was considered important to be executed by several strategies. The universities selected the students with 
good English proficiency, sent the prospective participants to language concern, and asked them to attend a three-month native language training. The respondent reported that "as much as three times a week, we were trained about a basic conversation in host country language and English within three months."

Host Country Demand

Responding to the demand, one of the universities (IAIN Tulungagung) set up a campus regulation to get a free tuition fee (scholarship) for some prospective students. In this case, the students are given free learning facilities, free access to the learning resources, and learning services. Meanwhile, the other universities responded to it by providing privileges to the intake students. The privilege is to convince that those intake students become the priority to be registered in the universities. Meanwhile, some others remain unresolved.

Necessitated Relevant Skills

Coping with the relevant skills must be mastered, some universities exposed the prospective candidates with teaching practicum, management practicum, and accounting practicum. Prior to their trip, they were trained on how to teach, how to deliver materials, how to manage the administrative things in the local government, how to negotiate, how to adapt the new culture, and how to socially communicate with the host community.

Cultural Diversities

Cultural diversity was another challenge of ISL implementation to be solved. The participants were introduced with cultural orientation and skills of teaching. They took one month of cultural orientation. The challenge may not affect too much the program, but it prevents from providing an optimal service.

Geographical Issues

The strategies to cope with the geographical issues done by the participants in the host country were asking for help the host community to accompany them to go to the schools, banks, or somewhere else, renting the motorcycle to the host community, and staying close to the places where they were doing services. In addition, the geographical challenges can be coped with by seeing more accessible communities. That is to say, more accessible spots for ISL were sought to replace the existing and previously selected spots.

\section{The Implementation of ISL: Background, the Roles of Stakeholders, and Procedures}

The six universities involved in this study implemented the ISL in Japan, Philippine, Singapore, Malaysia, and Thailand by employing the framework of three stages of implementation proposed by Baker-Boosamra et al. (2006a). These consisted of pre-trip activity, in-country activity, and post-trip follow up activity.

Pre-Trip Activities

Pre-trip activities, as the name suggests, deal with all preparation and orientation prior to the service learning in the host country. Schreier and Prugl (2011) said that without proper preparation prior to cultural and economic reality shifts, students risk missing the cultural exchange benefits. These included teaching practices and language training. Teaching practices are prepared for the participants with a non-education background; meanwhile, language training is conducted for all participants.

In addition to language preparation and teaching practicum, the participants are exposed to cultural and art orientation. This happens to UINSA and UMP. Different from UINSA and UMP, UMY provides a course of advocation. UIN Malik Ibrahim Malang only provides an academic orientation and geographical orientation. The orientations deal with subjects they need to teach and direction to the service learning points. In line with this, Matson and Barnas (2014) stated that a high degree of personal flexibility and cultural preparation resulted in more effective adaptation. 
The pre-trip activity also deals with contacting host partner agencies prior to students' placement. In an international setting, differences between university students and the host country's community are often much more apparent than such distinctions in domestic service learning programs. To minimize the diversities, a program's cooperative development will address a mutually established vision (Watzak et al., 2015). This also deals with the participants' arrival in the host country. Rather than familiarizing participants with their respective host agencies, an initiative is taken by the alumni from Indonesian Islamic Higher Education, they take part in introducing their host countries, and make the program run well. Form their involvement with prospective participants, they become familiar with each other. This happens naturally without any arrangement. However, Hetzell (2017) suggested that this would be better if faculty arranged sites for students and partnered with community agencies.

Another activity done in this pre-trip was to promote a deeper sense of reciprocal international understanding of culture and belief. The activity stipulates that there are some delegates from the host countries to take part in the program. They get exposed to a cultural presentation about life in Indonesia. The activity is not conducted by all universities since there are no delegates from the host countries who are intentionally invited. Conversely, a cultural presentation about life in the host country was carried out at UINSA. In this case, the participants from host country alumni present a cultural orientation as an addition to host country language preparation. "The students coming from Malaysia attended the coaching, and then they become coach."

In-Country Activities

The activities in this stage are formulated into convening a community assembly, conducting immersion and dialogue with the community, involving in service placement, and hosting a final conference day for students and host agency representatives. The discussion of these activities is presented in sequence, starting from the former to the latter.

Since most service learnings are conducted in the schools, the community assembly is carried out in schools where all members of the school community attend the activity. However, the community assembly conducted by the board of alumni is attended by more parties: "At the opening ceremony we invited the local army to be coached, but the General Consulate is involved in the third year. "In addition to the school community, other parties (such as General Consulates, Security Forces, and local government officials). This activity is in line with Niehaus \& Rothenberg (2013) statement that a community assembly should be convened upon the students' arrival in order to introduce students to the community and discuss the reasons for their presence. There is no specific information regarding what they talk and discuss during the community assembly; something in common is that the activity is set up in the opening of service learning.

They then need to conduct immersion and talk with the community. The immersion with the community is the core activity of service learning in which all participants stay in a period of time 0,5 - to 6 months in the society or school surroundings. The dialogues frequently happen in any activity. The participants conducting service learning in the schools talk about the materials to be presented to the students and the appropriate teaching strategies. Hartman and Rola (2000) noted that increased contact with host people yields greater satisfaction among students participating in the immersion experience.

Doing immersion and talk with the community will help the participants' confidence to be involved in service placements. Service placement is carried out by a local agent or individuals. Most participants conduct service learning in the schools; a few of them conduct the service learning at the bank and a few of them at the mosque and local government. The service learning conducted in Japan, Philippine, Singapore, Malaysia, and Thailand are mostly teaching activities. It means they provide service by teaching the community. This happens to 
the participants majoring education department or not. Therefore, all participants from different Departments are equipped with teaching skills prior to their trip to the host country. This service placement was once carried out in a study conducted by Baker-Boosmara et al. (2006) that in service placements, students learn about social work and provide a service to the host country.

At the end of the service place involvement, the universities under study, in collaboration with the local committee, hold a closing ceremony, it was found from the interviews with the respondents from UIN Sunan Ampel Surabaya. At this point, there is no specific information regarding the activity. One thing obvious from the closing ceremony is the evaluation that both parties express their gratitude and forgiveness. They were thankful for the services given to the community and forgave for the minimum services provided by the local community. The delegates from both parties commonly make the so-called small talks. In line with this, Keen and Hall (2008) remarked that this final conference day could also provide a venue for student or faculty-led evaluation of the various host agencies and a forum for the exchange of social work techniques and recommendations.

Post-Trip Follows Up and Continued Relationship Building

As suggested, the stage is to establish a means of on-going communication with counterparts in host countries. In fact, most universities conduct monitoring and evaluation with the participants in their country. In line with this, Baker-Boosmara et al. (2006) pointed out that continued communication in the form of regular and ongoing community-based program evaluation will ensure that the program continues to develop toward a mutually established vision, with mutually beneficial goals. The reports are made in different forms and types. Some universities (UMSU and UMP) assign the participants with online journals; some others (UMY, UIN Malik Ibrahim Malang, UINSA, and IAIN Tulungagung) ask the participants to jot down in a project report. The online journal is made daily and becomes a part of the stakeholders' assessment. In particular, the journal serves to provide a day-to-day report, an instrument for monitoring.

\section{The Challenges of the Implementation of ISL}

As identified that the participants dealt with some challenges during the implementation of ISL. The financial issues are predominating over the other challenges. They stem from different factors: transportation, ticket, prior to and after the trip, and living cost. There is always registration offer to the students since living cost in the host country is bigger than that of in domestic service learning and other expenses. It is obvious that the trip to go abroad needs a lot of money. Participants need to prepare twice, even three times bigger than the prescribed cost, anticipating any possible expenses. There is no specific problem regarding the cost of service learning in most Western countries since there are many funding resources. However, it is particularly true that ISL needs financial supports for implementing the program. "... revenue may be needed for professional staff development, transportation to community sites, or materials and equipment.” (Wilczenski \& Coomey, 2007).

Besides, the political issues are also encountered by the participants prior to and during their immersion in the host countries. The challenges may bring about a major problem if they are not properly managed. They can prevent the participants from getting access to the host countries. Alternatively, they go to jail due to incomplete identity. The challenges particularly happen to South Thailand, in which a gun attack frequently takes place between the local Army on one side and the rebels on the other side. Southeast Thailand frequently faces security crises, and this becomes an important issue for those who conduct ISL there. "As a whole, in this service site, students were exposed to language and culture, but also to very important current political and social issues facing Thailand and the entire Southeast Asian region (Hetzell, 2017).” 
In addition to the challenges, language mastery and cultural diversities are also becoming the barriers for the participants. Living overseas stipulates that the ISL participants be able to communicate in the target language and be culturally competent. Otherwise, they will encounter communication problems. This phenomenon is evident during their immersion with the local community in the host countries. Language barriers are the most obvious challenges encountered by the participants of ISL. According to Baker-Boosamra et al. (2006b), "The language barrier is an issue for both students and community members, but not a big problem," Further, it is stated that, "without at least a beginner's proficiency in the local language, students are unable to provide much care without the help of an interpreter (Reisch, 2011)."

Other challenges dealt with by the participants are host country's demand and necessitated relevant skills. Listening to the host country's demand would be wise for the continuation of the program (ISL). It is imperative that the universities, as service providers, assess the community needs prior to their implementation. Need assessment is a part of the steps to follow to promote customer satisfaction. In this case, a university should hear and listen to the local communities' voices that they are planning to serve (Baker-Boosamra, et al., 2006b). In line with this, it is suggested that the community identify its own need to get a reciprocal relationship (Pechak \& Thompson, 2009).

ISL participants are challenged to equip with the necessary skills in order for the services to be satisfactory. In service learning, teaching skills and language skills are important skills to acquire. "Teaching requires learning to adapt communication skills to meet the specific learning needs of the local people. Students may require learning new language skills to meet this expectation (Larsen \& Searle, 2017). For example, learning Spanish is a valuable skill that can be applied to most settings in the United States (Scott, 1990)."

Another challenge dealt with by the participants is geographical issues. It is stated that the gradual increase of difficulty in implementing the service learning may be influenced by the cultural or geographical distance between the host country and home country. Adapting to a new cultural environment may make the achievement of the desired outcomes more difficult. (Dykhouse \& Bikos David G Stewart, 2016) pointed out that travel to countries with different values and norms than the home country may be associated with increased difficulty with adaptation.

\section{The Strategies to Cope with the Challenges}

Of all the challenges mentioned, the universities strive to cope with them, and some are found resolved; however, some others remain unresolved. In relation to the financial issues, the strategies to cope with it was in line with the study conducted by Gura (2010) to the nursing students. They said that the faculty could commence the development of ISL by providing financial support for students to travel and developing the program's goals with an emphasis on service learning for public health. Regarding reciprocity as the strategy to cope with the political issues, Gura (2010) states that early gaps in ISL program tend to occur between the students and local partners. Hence, there is a need to design a reciprocity project to facilitate students' doing things (e.g., communicating, negotiating, inviting) with others.

In coping with the language barriers, the participants practiced doing conversation three times a week. This sense of general systematicity can be found on Larsen and Searle (2017). They find that some language training workshops require to be organized to explain to the students what is there in the ISL program for understanding nature and communication. Responding to the challenge of host country demand, one of the universities (IAIN Tulungagung) set up a campus regulation to get a free tuition fee (scholarship) for a number of the prospective students. In this case, the students are given free learning facilities, free 
access to the learning resources, and learning services. However, some others remain unresolved yet.

Coping with the lack of relevant skills, some universities exposed prospective candidates with teaching practicum. They are trained on how to teach and how to deliver materials. Prior to their trip, they have been equipped with teaching skills. The same strategy was adopted by Agarkar (2005) via driving the participants to engage in classroom teaching practices.

To cope with this, the participants are introduced with cultural orientation and skills of teaching. They take a one-day cultural orientation. In addition to this, the participants are struggling to find appropriate food that matches their appetites (Pechak \& Thompson, 2009). The challenge may not affect too much the program, but it prevents from providing an optimal service. In addition, another solution to the challenge was carried out by Nickols et al. (2013) that one thing to face the challenge is developing intercultural competence by sharing the mutual commitment between the participants and local community in the host country.

Having poor understanding to the host country culture predisposed the participants' perception to the acts of community. The effect of poor culture knowledge was studied by Pechak and Thompson (2009) that the participants are struggling to find appropriate food that match their appetites. The strategy to face this challenge is developing intercultural competence by sharing the mutual commitment between the participants and the local community in the host country (Pechak \& Thompson, 2009).

The geographical issues were dealt with by some participants from UMSU, IAIN Tulungagung, UMP, UMY, and UIN Malik Ibarahim Malang. It is stated that the gradual increase of difficulty in implementing the service learning may be influenced by the cultural or geographical distance between the host country and home country. Adapting to a new cultural environment may make the achievement of the desired outcomes more difficult. (Dykhouse \& Bikos David G Stewart, 2016) pointed out that travel to countries with different values and norms than the home country may be associated with increased difficulty with adaptation.

In a nutshell, the ISL experience was an arduous one in many participants, yet they gained challenges and suggested some strategies as the strategies to cope with. The following table is the stocktaking of the challenges and their strategies.

Table 3. The Stocktaking of the Challenges and Strategies of the ISL Implementation

\begin{tabular}{lll}
\hline \multicolumn{1}{c}{ Challenges } & & \\
\hline Financial issues & - & Taking land transportation \\
& - & Making an agreement (MoU) \\
& - & Collecting instalment payment from participants \\
\hline Political issues & - & Reducing the length of stay in the host country \\
& - & building an intensive communication with the local government \\
\hline Language barriers & - & Selecting students with a good proficiency in English \\
& - & Sending prospective participants to language concern \\
\hline Host country & - & Asking them to join a three month language training \\
demands & - & Assessing the community needs \\
& - & Listening to the local community voices \\
\hline Relevant skills & - & Setting up a campus regulation to provide scholarship to prospective students \\
& - & Exposing microteaching training \\
\hline Cultural diversities & - & Motivating the participants to engage in classroom practices \\
\hline Geographical issues & - & Conducting cultural orientation \\
& - & Conducting preliminary observation to the local community in the host country \\
\hline
\end{tabular}


The result of the research may be applicable for the Higher Education in Asian Contexts in which the Universities are lack of budget for the implementation with limited human resources. Some findings are believed to help the universities grow to be more globalized, and the participants are more interculturally competent (Kohlbry \& Daugherty, 2013; Watzak et al., 2015).

\section{CONCLUSION}

The present study describes the implementation of ISL among Islamic Higher Education Institutions in Indonesia, its challenges, and strategies. It was the first investigation of the emerging phenomenon of ISL in Islamic Higher Education institutions in Indonesia. Dealing with the implementation of ISL, it is structurally designed to follow the general characteristics of ISL. ISL among the IHEI in Indonesia, to a great extent, matches with the framework coined by Baker-Boosamra: Pre-trip activities, In-country activities, and Follow Up and continued Relationship Building. Within the framework of Pre-trip activities, all indicators are met, except for the cultural presentation about life in the country of participants to promote a deeper sense of reciprocal international understanding, increasing the benefit of the student's presence to partners.

Similarly, within the framework of In-Country Activities, most indicators are met except for Hosting a final conference day for students and host agency representatives. Within the framework of Post -Trip Follow Up and continued Relationship Building, the ISL among the IHEI mostly ends with a closing ceremony, and no commitment is made. In addition, they have no specific concept of building a further relationship between the IHEIs and the host countries.

With respect to the challenges, it is generally found that the ISL among IHEIs in Indonesia encounter the following challenges: financial challenges, political challenges, language barriers, host country demands, relevant skills, cultural challenges, and geographical challenges. They are mostly encountered by the participants rather than the host countries or stakeholders. To cope with the challenges above, the following strategies - presented following the sequence above-were made: setting up a less money- generating policy, making an MoU, collecting instalment payment, and reducing the length of stay in the host country; building an intensive communication with the local government and having an ID card from local government; getting the participants to get more exposed to the target language; positively responding the host country demand; preparing the participants with the relevant and necessitated skills-microteaching and engaging in the classroom practices; conducting host culture orientation and developing intercultural competence, and finding more accessible spots in the host country by conducting a preliminary survey prior to the implementation.

In general, it is found that the ISL among IHEI in Indonesia has no specific successful indicators, derived from thorough need analysis. The minimal efforts are made, but they do not cover all necessary components, such as the skills needed, the area of study, the characteristics of regions, and the types of target communities. Responding to the weak points of ISL among IHEIs in Indonesia, the paper recommends that the ISL have good planning in all implementation stages. That is to say, the specific indicators of successful implementation have to be made by referring to the formulated objectives, derived from thorough need analysis.

\section{BIBLIOGRAPHY}

Agarkar, S. (2005) An Introductory Course On School Science Education. Mumbai: HBCSE.

Amerson, R. (2014). Research-based recommendations for implementing international servicelearning. Journal of Professional Nursing, 30(2), 175-179. https://doi.org/10.1016/j. profnurs.2013.09.006

Ansor, S. (2017). Studi Meta Analisis Strategi dan Pemanfaatan Jurnal Elektronik (e -journals) untuk Mahasiswa Lulusan Universitas Negeri Malang dalam Upaya Publikasi Ilmiah Bereputasi Internasional Study Meta Analysis of Strategies and Utilization of Electronic Journals. 3(1). 
Baker-Boosamra, M., Guevara, J. A., \& Balfour, D. L. (2006a). From Service to Solidarity: Evaluation and Recommendations for International Service Learning. Journal of Public Affairs Education, 12(4), 479-500. https://doi.org/10.1080/15236803.2006.12001452

Baker-Boosamra, M., Guevara, J. A., \& Balfour, D. L. (2006b). From Service to Solidarity: Evaluation and Recommendations for International Service Learning. Journal of Public Affairs Education, 2(1), 479-500. https://doi.org/10.1271/bbb.100261

Brown, B. E. (2015). The Growth of Civic Engagement Through International Service Learning in Dance. https://cloudfront.escholarship.org/dist/prd/content/qt18g3j9k3/qt18g3j9k3.pdf

Cheryl Keen, \& Kelly Hall. (2008). Engaging with Difference Matters: Longitudinal Student Outcomes of Co-Curricular Service-Learning Programs. The Journal of Higher Education, 80(1), 59-79. https://doi.org/10.1353/jhe.0.0037

Chiu, S.-F. (2015). Service Learning, Workplace Probation, and the Growth of the Spirituality. Procedia - Social and Behavioral Sciences, 171, 17-23. https://doi.org/ 10.1016/j.sbspro.2015. 01.083

Dykhouse, E. C., \& Bikos David G Stewart, L. H. (2016).Digital Commons@SPU International Interests and Psychological Well- Being Following Global Service Learning as a Function of Sociocultural Adaptation and Cultural Distance International Interests and Psychological Well-Being Following Global Service Learning as a Function of Sociocultural Adaptation and Cultural Distance. http://digitalcommons.spu.edu/cpy_etd

Furco, A. (1996). Is service-learning really better than community service. Service Learning, General, 23-50. http://digitalcommons.unomaha.edu/slceslgen

Gaines-Hanks, N., \& Grayman, N. (2009). International service-learning in South Africa and personal change: An exploratory content analysis. Journal of Student Affairs Research and Practice, 46(1), 72-94. https://doi.org/10.2202/1949-6605.5006

Gall, M. D., Borg, W. R., \& Gall, J. P. (2003). Educational research: An introduction (7th ed.). White Plains, New York: Pearson/Allyn \& Bacon.

Gura, S. T. (2010). Mindfulness in occupational therapy education. In Occupational Therapy in Health Care (Vol. 24, Issue 3, pp. 266-273). Jones and Barlett. https://doi.org/10.3109/07380571003770336

Hartman, D., \& Rola, G. (2000). Going Global with Service Learning. Metropolitan Universities, 11(1), 15-23.

Hetzell, L. B. (2017). Managing Transformation: How Do Undergraduate Students Experience: the Process of Reentry after International Service Learning?' Temple University.

Kohlbry, P., \& Daugherty, J. A. (2013). Nursing faculty roles in international service-learning projects. Journal of Professional Nursing, 29(3), 163-167. https://doi.org/10.1016/j.profnurs.2012.04.018

Kohlbry, P., \& Daugherty, J. A. (2015). International Service-Learning: An Opportunity to Engage in Cultural Competence. Journal of Professional Nursing, 31(3), 242-246. https://doi.org/10.1016/j.profnurs.2014.10.009

Larsen, M. A., \& Searle, M. J. (2017). International service learning and critical global citizenship: A cross-case study of a Canadian teacher education alternative practicum. Teaching and Teacher Education, 63, 196-205. https://doi.org/10.1016/j.tate.2016.12.011

Matson, K. L., \& Barnas, C. E. (2014). Jamaican a difference: A grassroots approach by pharmacy students to develop an international service learning experience. Currents in Pharmacy Teaching and Learning, 6(6), 856-863. https://doi.org/10.1016/j.cptl.2014.07.008

Nickols, S., Rothenberg, N., Moshi, L., \& Tetloff, M. (2013). International Service-Learning: Students' Personal Challenges and Intercultural Competence. Journal of Higher Education Outreach and Engagement, 17(4), 97-124. 
Niehaus, E., \& Crain, L. K. (2013). Act local or global?: Comparing student experiences in domestic and international service-learning programs. Michigan Journal of Community Service Learning, 20(1), 31-40. http://libaccess.mcmaster.ca /login?url=http:// search.proquest. $\mathrm{com} /$ docview/ 1651865347?accountid $=12347$

Pechak, C. M., \& Thompson, M. (2009). A Conceptual Model of Optimal International Service-Learning and Its Application to Global Health Initiatives in Rehabilitation. Physical Therapy, 89(11), 1192-1204. https://doi.org/10.2522/ptj.20080378

Reisch, R. A. (2011). International service learning programs: Ethical issues and recommendations. Developing World Bioethics, 11(2), 93-98. https://doi.org/10.1111/j.1471-8847.2011.00299.x

Schreier, M., \& Prügl, R. W. (2011). Promoting Corporate Social Responsibility and Sustainable Development Through Management Development: What Can be Learned from International Service Learning Programs. Library, 1(September), 269-288. https://doi.org/10.1007/s10551-011-0925-7

Scott, J. M. (1990). Research Demonstrates the Value of Service Learnin. February, 247-255.

Watzak, B., Engelhardt, J. A., Bentley, R., \& Self, D. J. (2015). Assessment of ethics and values during an interprofessional, international service learning experience. Currents in Pharmacy Teaching and Learning, 7(4), 526-535. https://doi.org/10.1016/j.cptl.2015.04.002

Wilczenski, F. L., \& Coomey, S. M. (2007). A Practical Guide to Service Learning: Strategies for positive development in schools. In A Practical Guide to Service Learning: Strategies for Positive Development in Schools. https://doi.org/10.1007/0-387-46540-5

Yin, X., Zhang, J., \& Wang, X. (2004). Sequential injection analysis system for the determination of arsenic by hydride generation atomic absorption spectrometry. Fenxi Huaxue, 32(10), 1365-1367. https://doi.org/10.1017/CBO9781107415324.004 